\title{
Arctic river-runoff: mean residence time on the shelves and in the halocline
}

\author{
Peter Schlosser, ${ }^{*} \dagger$ Dorothea Bauch, ${ }^{*} \ddagger$ Richard Fairbanks $* \dagger$ and \\ Gerhard BönISCH* $\ddagger$
}

(Received 20 November 1992; in revised form 3 May 1993; accepted 13 May 1993)

\begin{abstract}
The mean residence time of river-runoff on the shelves and in the halocline of the Arctic Ocean is estimated from salinity and tracer data (tritium, ${ }^{3} \mathrm{He}$ and the ${ }^{18} \mathrm{O} /{ }^{16} \mathrm{O}$ ratio). These estimates are derived from comparison of apparent tracer ages of the halocline waters using a combination of tracers that yield different information: (1) the tritium "vintage" age, which records the time that has passed since the river-runoff entered the shelf; and (2) the tritium ${ }^{3} \mathrm{He}$ age, which reflects the time since the shelf waters left the shelf. The difference between the ages determined by these two methods is about $3-6$ years. Correction for the initial tritium $/{ }^{3} \mathrm{He}$ age of the shelf waters (about $0.5-1.5$ years) yields a mean residence time of the river-runoff on the shelves of the Siberian Seas of about $3.5 \pm 2$ years.
\end{abstract}

\section{INTRODUCTION}

THE upper water column in the Arctic Ocean is dominated by a strong halocline that separates the fresh Polar Surface Water from the underlying Atlantic-derived waters. The halocline is formed by freshwater added from river-runoff or sea ice meltwater to the surface waters. The halocline waters store a significant amount of freshwater which finally is exported from the Arctic Ocean through Fram strait via the East Greenland Current. Part of the freshwater transported in the East Greenland Current mixes into the center of the convective gyres of the Greenland and Labrador Seas, and influences in this way the delicate salinity balance of their surface waters. Variations in the supply of freshwater to the surface waters of the gyres may have significant influence on the strength of deep convection (AAGAARD and CARMACK, 1989), on the associated deep water formation (e.g. Greenland Sea Project Group, 1990; Schlosser et al., 1991), and thus on the deep circulation of the world ocean.

The salinity balance of the Arctic Ocean surface waters is influenced by the supply of freshwater from rivers discharging onto the Arctic shelves. The total freshwater inventory of the shelves exceeds the annual freshwater input (e.g. HANZlick and AAgaARD, 1980) and they act as a short-term buffer, moderating variations in the amount and composition of the freshwater. The runoff signal is also modified by mixing with halocline water and

\footnotetext{
${ }^{*}$ Lamont-Doherty Earth Observatory of Columbia University, Palisades, NY 10964, U.S.A.

†Department of Geological Sciences, Columbia University, New York, U.S.A.

†Institut für Umweltphysik der Universität Heidelberg, Im Neuenheimer Feld 366, D-69120 Heidelberg, Germany.
} 
sea ice meltwater during transport from the shelves to Fram Strait. Both factors have to be known for a proper understanding or the influence of variations in Arctic river-runoff on the salinities of the central gyres in the Greenland/Norwegian/Iceland and Labrador Seas.

Previously, the mean residence time of shelf waters in the Arctic Ocean has been determined on the basis of mass balances (e.g. HANZLICK and AAGAARD, 1980; AAGAARD and COACHMAN, 1975). In this contribution we use tracer data from the Arctic halocline to derive an independent estimate of the mean residence time of the shelf waters in the Arctic Ocean.

\section{METHOD}

Our principle approach is to compare various tracer derived ages of halocline waters known to be formed on the shelves of the Arctic Ocean (e.g. AAGAARD et al., 1981; Jones and Anderson, 1986). In the Eurasian Basin, halocline waters consist of a mixture of Atlantic water and a freshwater component (river-runoff and sea ice meltwater). Certain tracers delivered to the shelf by river-runoff start to "age" at the time they enter the shelf. Other tracers are in contact with the atmosphere on the shelf and their clock is set to zero only when they leave the shelf and submerge below Arctic Ocean surface water or ice cover. We can use the difference between these two tracer-derived ages to determine the mean residence time of the river-runoff component on the shelf.

ÖSTLUND and Hut (1984) pointed out that the combination of salinity, tritium and ${ }^{18} \mathrm{O}$ can be used to distinguish between river-runoff and sea ice meltwater contained in the freshwater component of the Arctic halocline and to determine the mean age of the riverrunoff component. In their approach, they first use salinity and ${ }^{18} \mathrm{O}$ to calculate the fractions of river-runoff and sea ice meltwater in the individual water samples. In a second step they calculate the tritium concentration of the river-runoff component using a hydrological model and compare this value to the tritium concentrations as a function of time in the Siberian rivers (estimated by ÖSTLUND, 1982) to obtain the so-called "tritium vintage age". Applying this method to halocline waters yields an estimate of the mean time that has passed since the river-runoff fraction contained in a water parcel of the halocline was discharged onto the shelf. This time is a measure for the total time spent on the shelf as well as the travel time from the shelf edge to the sampling site.

The tritium $/{ }^{3} \mathrm{He}$ age is set to zero in a different way. ${ }^{3} \mathrm{He}$ formed in the shelf waters by tritium decay is lost to a large degree to the atmosphere by gas exchange. Thus, the tritium $/{ }^{3} \mathrm{He}$ age is close to zero for shelf waters. The "tritium $/{ }^{3} \mathrm{He}$ clock" is started at the time when the shelf waters flow into the interior basin and gas exchange with the atmosphere is suppressed by sea ice and/or overlying water layers. Tritium/ $/{ }^{3} \mathrm{He}$ ages of the Arctic halocline therefore should be lower than the tritium vintage ages. The same should hold for all ages derived from gases dissolved in seawater (e.g. CFCs). The few published data are in agreement with this concept (ÖstLUND and HUT, 1984; ÖsTLUND et al., 1982; Schlosser, 1985; Schlosser et al., 1990; Wallace and Moore, 1985; Wallace et al., 1987, 1992).

\section{SAMPLE COLLECTION AND MEASUREMENT}

The data used in this study were collected during the 1987 cruise of the German research icebreaker Polarstern to the Nansen Basin of the Arctic Ocean. During this cruise, a 

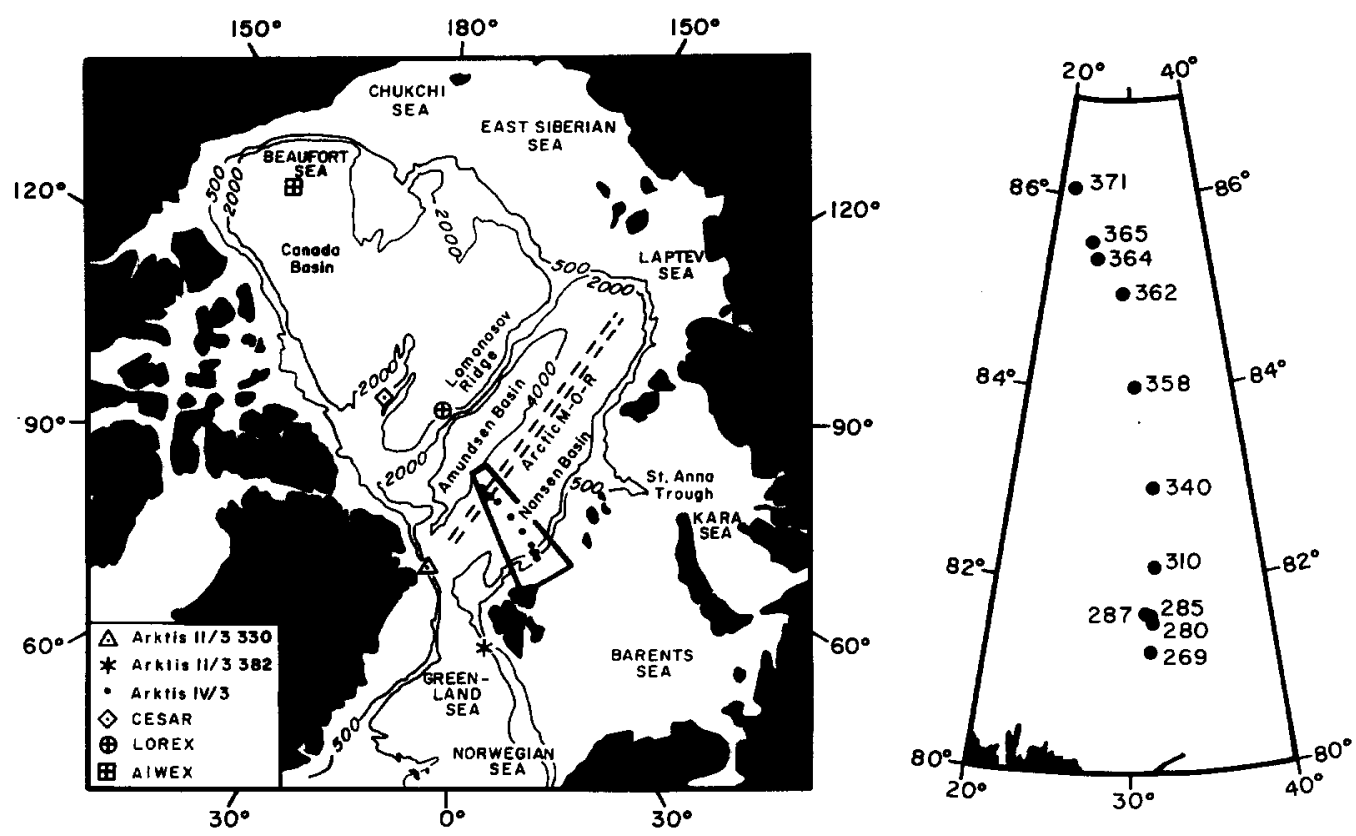

Fig. 1. Geographic positions of the ARK IV/3 stations.

hydrographic section across the Nansen Basin included sampling for a variety of tracers (for a detailed description of the cruise, see PSSP, 1988; ANDERSON et al., 1989). Here we use tritium, ${ }^{3} \mathrm{He}$ and ${ }^{18} \mathrm{O}$ data from a section reaching from the Barents Shelf to the Gakkel Ridge (Fig. 1).

All tritium $/{ }^{3} \mathrm{He}$ and part of the ${ }^{18} \mathrm{O}$ samples were measured at the Institute for Environmental Physics at the University of Heidelberg. Most of the ${ }^{18} \mathrm{O}$ samples were measured at the Lamont-Doherty Earth Observatory. Tritium samples were measured mass spectrometrically using the ${ }^{3} \mathrm{He}$ ingrowth technique (BAYER et al., 1989). Precision of the measurements is about $\pm 2 \%$. Tritium data are reported in tritium units (TU). One TU means a tritium to hydrogen ratio of $10^{-18} .{ }^{3} \mathrm{He} /{ }^{4} \mathrm{He}$ ratios were measured with a precision of about $\pm 0.2 \%$ and are reported in the $\delta$ notation where $\delta^{3} \mathrm{He}$ means the percent deviation of the ${ }^{3} \mathrm{He} /{ }^{4} \mathrm{He}$ ratio of a sample from that of an air standard $\left({ }^{3} \mathrm{He} /{ }^{4} \mathrm{He}\right.$ ratio: $1.384 \times 10^{-6}$; CLARKE et al., 1976). ${ }^{18} \mathrm{O}$ measurements were performed on a commercial mass spectrometer after equilibration of $\mathrm{CO}_{2}$ with the water sample. ${ }^{18} \mathrm{O}$ results are reported in the $\delta$ notation where $\delta^{18} \mathrm{O}$ is the per mill. deviation of the ${ }^{18} \mathrm{O} /{ }^{16} \mathrm{O}$ ratio of the sample from that of SMOW (Standard Mean Ocean Water). Precision of the Heidelberg ${ }^{18} \mathrm{O}$ data is typically $\pm 0.07 \%$ while precision of the L-DGO ${ }^{18} \mathrm{O}$ data is about $\pm 0.02-$ $0.03 \%$.

\section{HYDROGRAPHIC FEATURES}

The halocline waters extend throughout the Arctic Ocean below a relatively homogeneous surface layer with temperatures close to the freezing point of seawater and above a 


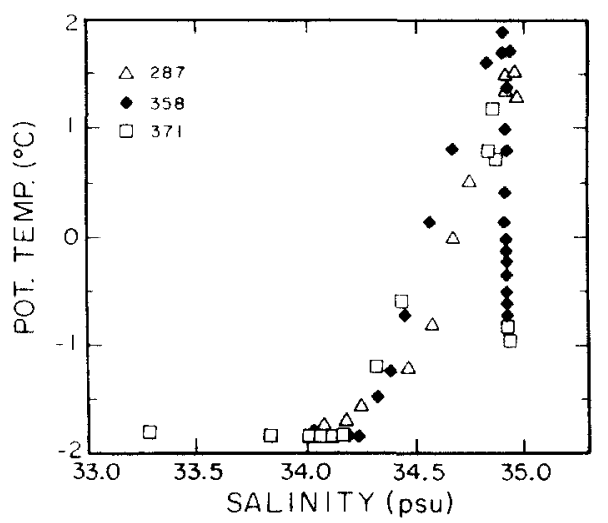

Fig. 2. Potential temperature versus salinity plot for stations from the southern (287), central (358) and northern (371) part of the 1987 Polarstern section (for geographic positions, see Fig. 1).

distinct intermediate temperature maximum caused by an advective core of Atlantic water (AAGAARD et al., 1981). The halocline waters are formed and maintained by advection of shelf waters into the central basins (AAgAard et al., 1981). Jones and ANDERSON (1986), using chemical properties in addition to temperature and salinity data, distinguished between upper and lower halocline waters. The upper halocline waters are characterized by salinities of about 33.1 (psu), temperatures close to the freezing point of seawater and distinct nutrient maxima, while the lower halocline waters have salinities of about 34.25 , temperatures close to the freezing point of seawater and a pronounced NO minimum (see also JoNes et al., 1991). There are indications that the upper halocline waters originate in the Chukchi Sea while the lower halocline waters are formed in the Barents and Kara seas (e.g. Jones and Anderson, 1986; Jones et al., 1991).

Temperature/salinity information from selected stations of the 1987 Polarstern section (Fig. 2) indicates that the upper halocline is more or less completely missing in our Nansen Basin section. The lower salinities observed at the northern end of the section (Sta. 371) are due to the influence of increased river-runoff. The halocline waters therefore fall around a more or less linear $T / S$ line between the Atlantic water and the core of lower halocline waters as defined by JONES and ANDERSON (1986).

\section{RESULTS}

$\delta^{18} \mathrm{O}$ values increase to the south and with depth to reach a maximum of about $0.3 \%$ at about $300-500 \mathrm{~m}$, i.e. in the core of the Atlantic Water (Fig. 3a and 3c; for comparison with salinity, see Fig. 3b). The surface values are relatively high on the Barents Shelf (about $0.15 \%$ at Sta. 269 ; Fig. 3a) and decrease with latitude to reach minimum values of about $-1.6 \%$ at sta. 371 . This trend in the ${ }^{18} \mathrm{O}$ pattern reflects the higher runoff fraction in the surface waters of the central basin. Below the Atlantic water, $\delta^{18} \mathrm{O}$ values are more or less constant to a depth of about $2500 \mathrm{~m}$. At this depth there seems to be a slight increase in $\delta$ ${ }^{18} \mathrm{O}$ by about $0.05-0.1 \%$ (Fig. $3 \mathrm{c}$ ). The $2500 \mathrm{~m}$ isobath is close to the sill depth separating the Arctic Ocean from the Greenland Sea. Therefore, the decrease in $\delta^{18} \mathrm{O}$ above $2500 \mathrm{~m}$ might mark the influence of lower salinity waters transported from the Greenland/ Norwegian seas into the Arctic Ocean. 

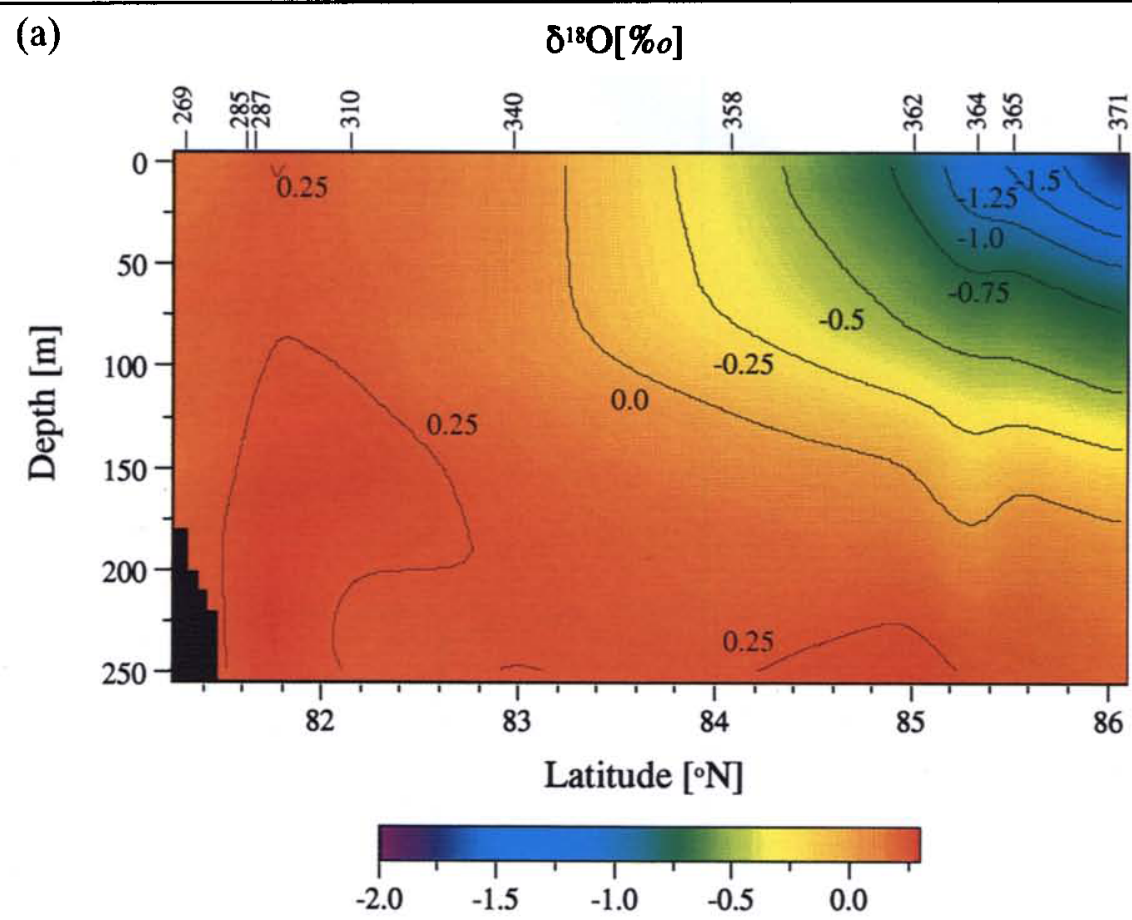

(b)

\section{Salinity [psu]}

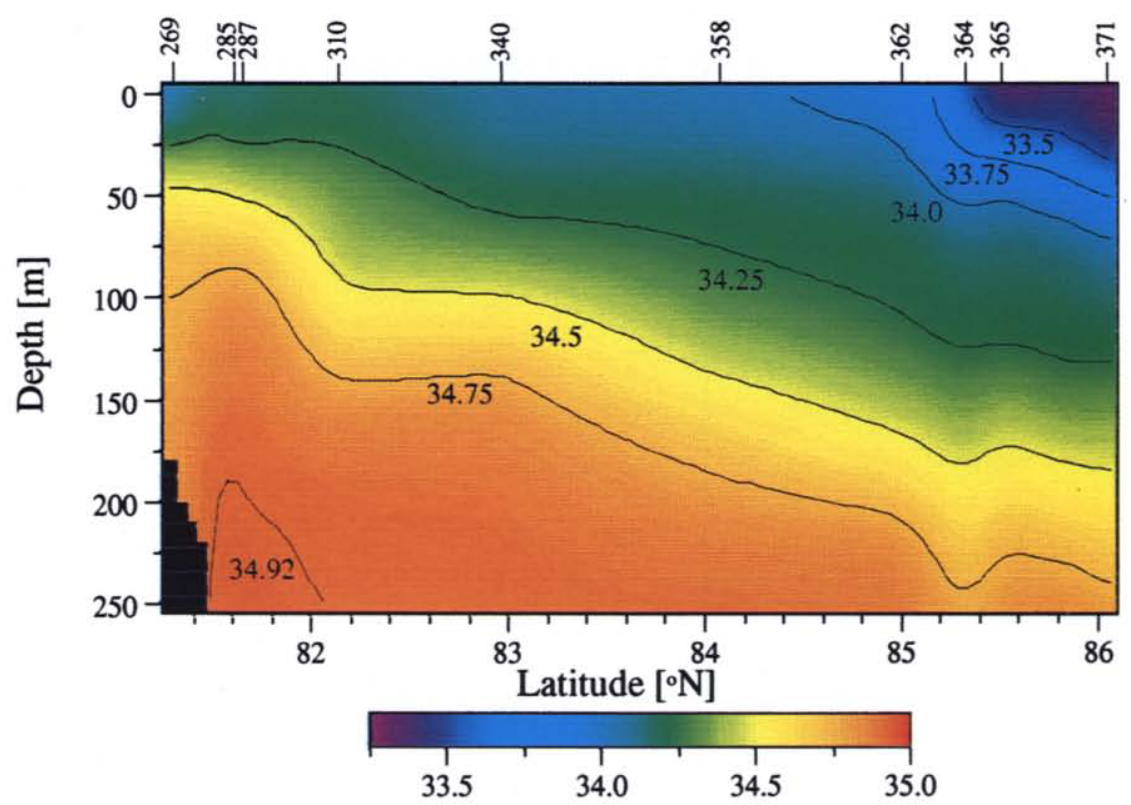

Fig. 3. (a) $\delta^{18} \mathrm{O}$ section of the upper $250 \mathrm{~m}$ of the water column extending from the Barents Shelf (Sta. 269) to the Gakkel Ridge (Sta. 371; for geographical position of the stations, see Fig. 1). (b) Same as (a) for salinity. (c) $\delta^{18} \mathrm{O}$ versus depth plot of Sta. 358 extending over the entire water column. 


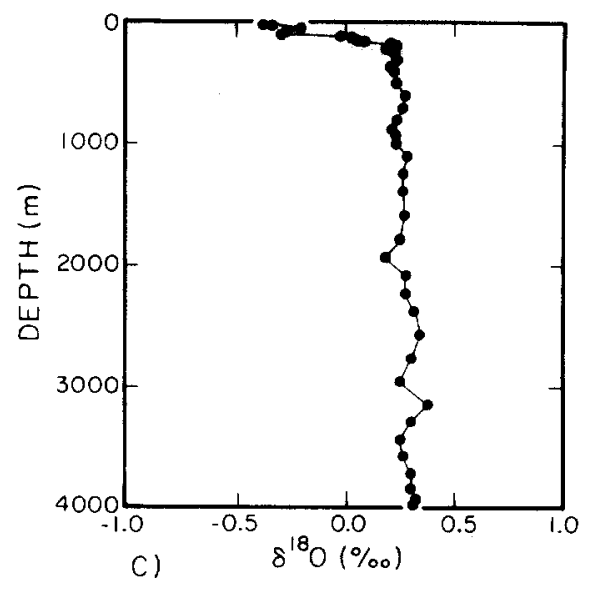

Fig. 3. Continued. 
(a)

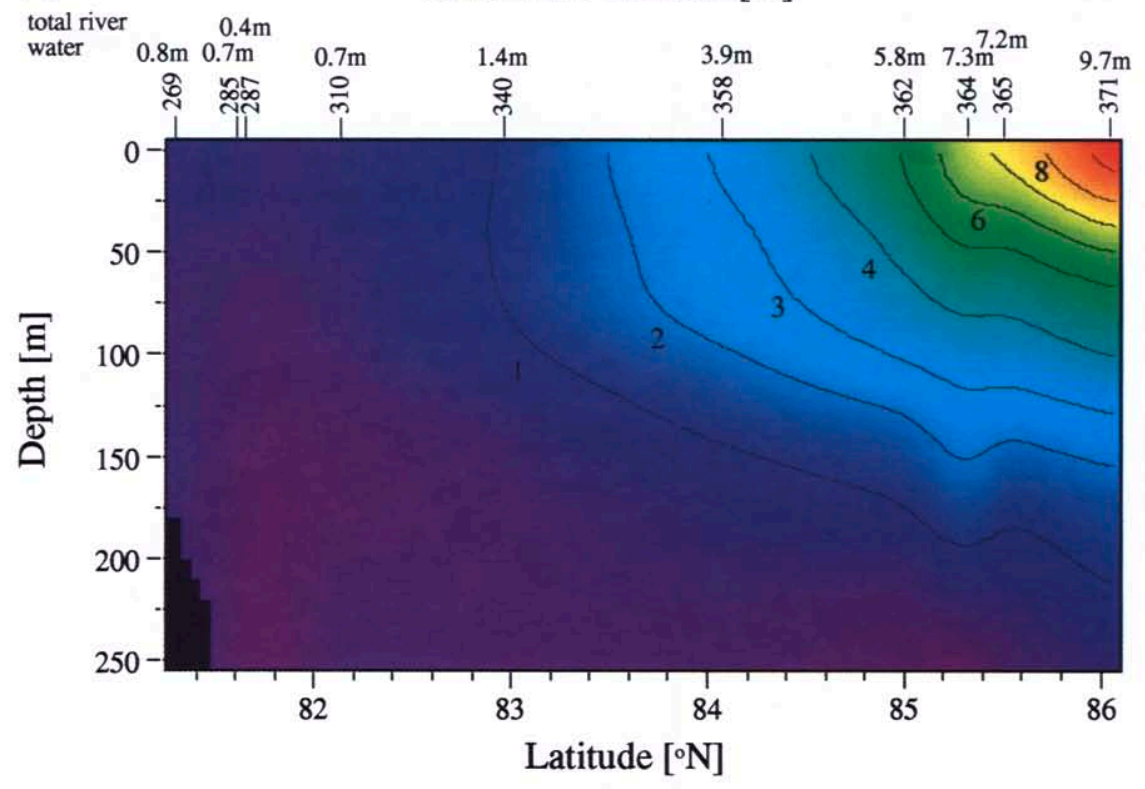

(b)
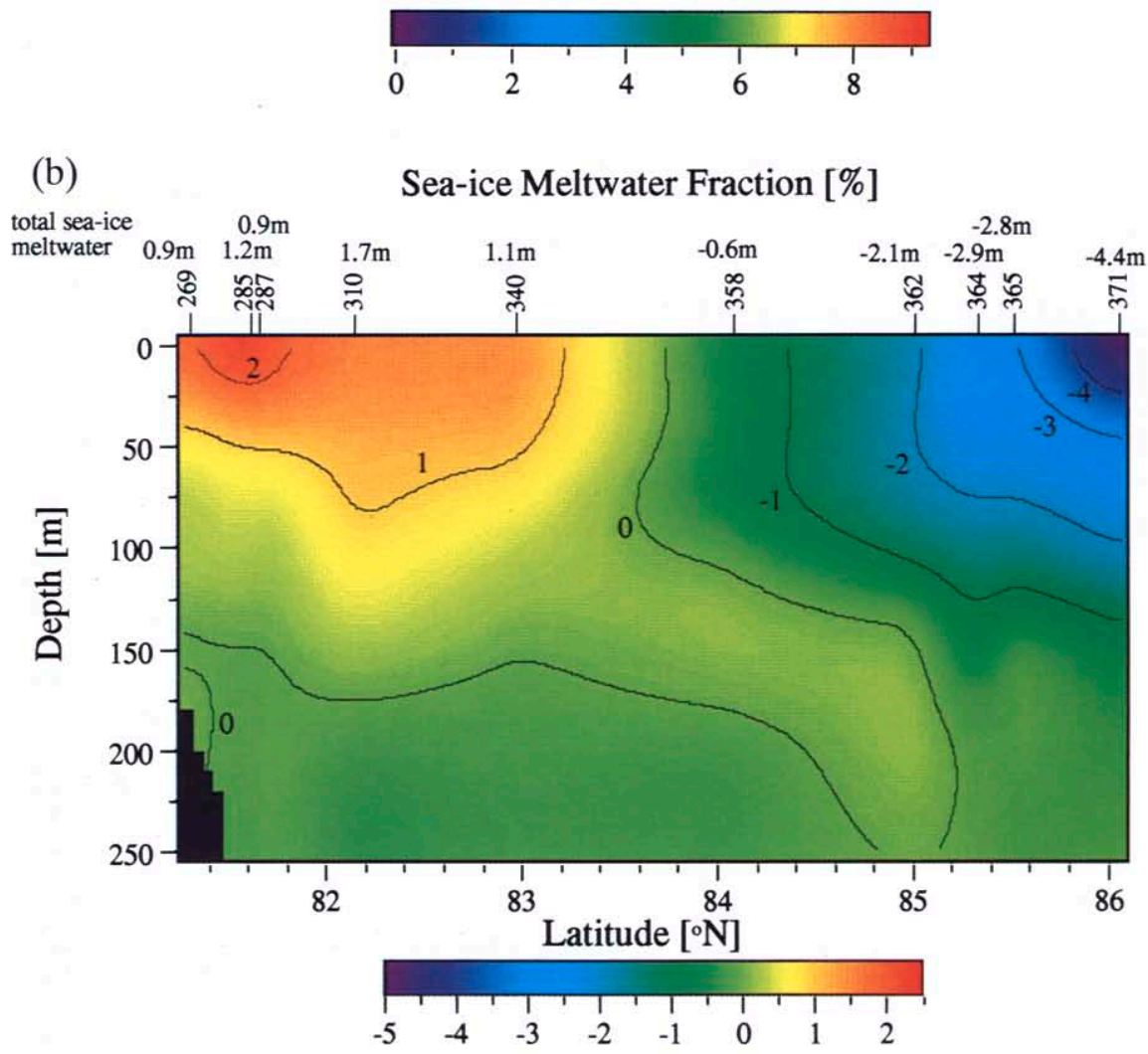

Fig. 6. (a) Same as Fig. 4 for the fraction of river-runoff contained in the halocline water. The fraction of river-runoff is given in percent. (b) Same as Fig. 4 for the fraction (in percent) of sea ice meltwater contained in the halocline waters. Positive numbers mean addition of freshwater by melting of sea ice; negative numbers indicate formation of sea ice (removal of freshwater). 





Fig. 4. Tritium section of the upper $250 \mathrm{~m}$ of the section extending from the Barents Shelf (Sta. 269) to the Gakkel Ridge (Sta. 371; for geographical position of the stations, see Fig. 1).

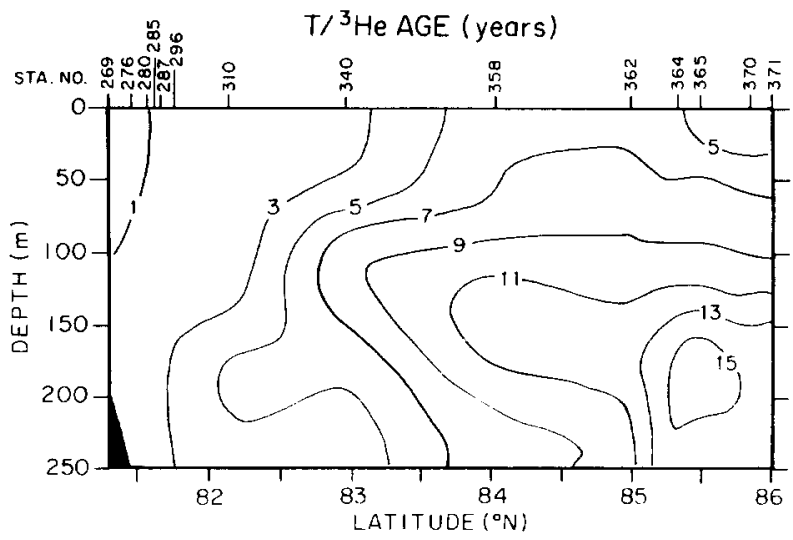

Fig. 5. Same as Fig. 4 for tritium $/{ }^{3} \mathrm{He}$ age.

The tritium section (Fig. 4) shows a pattern similar to $\delta^{18} \mathrm{O}$ with maximum concentrations of about $10 \mathrm{TU}$ in the surface waters of the northernmost station (Sta. 371) and relatively low concentrations on the Barents Shelf (about 3.5 TU at Sta. 269). The tritium concentrations in the Atlantic water are fairly homogeneous between the Barents Shelf and the northern boundary of the Nansen Basin, with values of about 3.3-4.5 TU.

The apparent ${ }^{3} \mathrm{H} /{ }^{3} \mathrm{He}$-age of the surface water (Fig. 5) increases from the Barents Shelf (about 1 year) towards the northern Nansen Basin where they reach values between about 3 and 5 years at Sta. 371. There is a ${ }^{3} \mathrm{H} /{ }^{3} \mathrm{He}$-age maximum at intermediate depths at stations located in the central Nansen Basin, caused by the fact that relatively young Atlantic water underlies relatively old water of the lower halocline. This feature disappears at stations in the northern Nansen Basin (e.g. Sta. 371) where the Atlantic water is 
older than further south. At these northern stations, the ${ }^{3} \mathrm{H} /{ }^{3} \mathrm{He}$-age increases more or less monotonically with depth.

\section{DISCUSSION}

\section{River-runoff versus sea ice meltwater}

As discussed in detail by ÖsTLunD and Hut (1984), a combined salinity $/^{18} \mathrm{O}$ balance can be used to distinguish between river-runoff and sea ice meltwater in the freshwater component of the halocline. The balance is governed by the following equations

$$
\begin{aligned}
f_{\mathrm{a}}+f_{\mathrm{r}}+f_{\mathrm{i}} & =1 \\
f_{\mathrm{a}} * S_{\mathrm{a}}+f_{\mathrm{r}} * S_{\mathrm{r}}+f_{\mathrm{i}} * S_{\mathrm{i}} & =S_{\mathrm{m}} \\
f_{\mathrm{a}} * O_{\mathrm{a}}+f_{r} * O_{\mathrm{r}}+f_{\mathrm{i}} * O_{\mathrm{i}} & =O_{\mathrm{m}} .
\end{aligned}
$$

Where $f_{\mathrm{a}}, f_{\mathrm{r}}$ and $f_{\mathrm{i}}$ are the fractions of Atlantic water, river-runoff and sea ice meltwater in a halocline water parcel, and $S_{\mathrm{a}}, S_{\mathrm{r}}, S_{\mathrm{i}}, O_{\mathrm{a}}, O_{\mathrm{r}}$ and $O_{\mathrm{i}}$ are the corresponding salinities and $\delta^{18} \mathrm{O}$ values. $S_{\mathrm{m}}$ and $O_{\mathrm{m}}$ are the measured salinity and $\delta^{18} \mathrm{O}$ of the halocline water.

For the Atlantic water, the salinity is set to 34.92 and $\delta^{18} \mathrm{O}$ to $0.30 \%$. The choice of the $\delta^{18} \mathrm{O}$ value is based on direct measurements by ÖSTLUND and HuT (1984) and on our own data. The $\delta^{18} \mathrm{O}$ value for river-runoff $\left(S_{\mathrm{r}}=0\right)$ is set to $-21 \%$ following ÖsTLUND and HuT (1984). The $\delta^{18} \mathrm{O}$ values of sea ice ( $S_{\mathrm{i}}$ is set to $3 \%$ ) are variable (Pfirman et al., 1990). This fact has to be taken into account when estimating the $\delta^{18} \mathrm{O}$ of sea ice meltwater. As we do not know where the sea ice that contributes to the freshwater component of a specific water parcel is formed, and the $\delta^{18} \mathrm{O}$ value of the water from which it is formed is usually unknown, we assume that the sea ice meltwater has the same $\delta^{18} \mathrm{O}$ value as the surface water of the station for which the freshwater balance is estimated multiplied by a fractionation factor. ${ }^{18} \mathrm{O}$ fractionation during sea ice formation leads to enrichment of the heavier oxygen isotope in the ice. The fractionation factor for seawater is well known for equilibrium conditions (about 1.0028; BECK and MÜNNICH, 1988). For dynamic conditions under which sea ice is formed in the Arctic Ocean, the fractionation factor is lower. Because we have no reliable data on the sea ice growth rate and the related variable fractionation factor, we use the equilibrium fractionation factor in our calculations. Variations within reasonable limits in the assumptions made for both the $\delta^{18} \mathrm{O}$ values of the sea ice meltwater $(0$ to $-2.7 \%$ ) and the fractionation factor for sea ice formation $(0$ $2.8 \%$ ) affect our estimates of the river-runoff fraction by \pm 1 and $\pm 0.5 \%$, respectively.

Using equations (1)-(3) and the salinity and oxygen isotope values for the individual water masses, we can calculate the fractions of Atlantic water, sea ice meltwater and riverrunoff (Table 1; Fig. 6). Near the Barents Shelf the freshwater component is dominated by sea ice meltwater. The river-runoff fraction in the freshwater increases with increasing distance from the Barents Shelf. At Sta. 358 and at stations further north, the freshwater component consists practically exclusively of river-runoff, and part of the freshwater has been used to form sea ice. The river-runoff signal is a good indicator of the Eurasian Branch of the Transpolar Drift, the southern boundary of which lies close to Sta. 358 (Anderson et al., 1989; Jones et al., 1991; Pfirman et al., 1990).

Because sea ice formation adds significant amounts of salt but influences the ${ }^{18} \mathrm{O}$ balance only slightly due to the small fractionation factor, the $\delta^{18} \mathrm{O}$ versus salinity plot for 
Table 1. List of the hydrographic parameters together with the $\delta^{18} \mathrm{O}$, tritium, and ${ }^{3} \mathrm{He}$ measurements of halocline waters (salinity <34.5) from the 1987 Polarstern section. The fractions of Atlantic water $\left(\mathrm{f}_{a}\right)$, sea-ice meltwater $\left(\mathrm{f}_{i}\right)$ and river-runoff $\left(\mathrm{f}_{\mathrm{r}}\right)$ as well as the tritium concentrations in river-runoff calculated from equation (4) $\left({ }^{3} \mathrm{H}_{\text {runoff }}\right)$ are also listed. $L$ stands for samples measured at $L-D E O, H$ for samples measured at Heidelberg

\begin{tabular}{|c|c|c|c|c|c|c|c|c|c|c|c|c|}
\hline Sta. & Depth & $\theta$ & Salinity & $\delta^{18} \mathrm{O}$ & Lab. & ${ }^{3} \mathrm{H}$ & $f_{\mathrm{i}}$ & $f_{\mathrm{r}}$ & $f_{\mathrm{a}}$ & ${ }^{3} \mathbf{H}_{\text {runoff }}$ & $\begin{array}{c}\text { Vintage } \\
\text { age }\end{array}$ & ${ }^{3} \mathrm{H} /{ }^{3} \mathrm{He}$-age \\
\hline 269 & 3 & -1.66 & 34.094 & 0.252 & $\mathrm{~L}$ & 3.66 & 2.1 & 0.5 & 97.5 & - & - & 0.4 \\
\hline 269 & 9 & -1.66 & 34.108 & 0.11 & $\mathbf{H}$ & 3.43 & 1.4 & 1.1 & 97.6 & - & - & 0.3 \\
\hline 269 & 20 & -1.64 & 34.154 & 0.241 & $\mathrm{~L}$ & 3.55 & 1.8 & 0.5 & 97.6 & - & - & 0.4 \\
\hline 269 & 40 & -1.14 & 34.450 & 0.14 & $\mathrm{H}$ & 3.53 & 0.6 & 0.8 & 98.6 & - & - & 0.7 \\
\hline 285 & 31 & -1.70 & 34.202 & 0.22 & $\mathbf{H}$ & 3.41 & 1.6 & 0.6 & 97.8 & - & - & 1.5 \\
\hline 287 & 10 & -1.75 & 34.077 & 0.274 & $\mathrm{~L}$ & - & 2.2 & 0.4 & 97.4 & - & - & - \\
\hline 287 & 31 & -1.71 & 34.180 & 0.241 & $\mathrm{~L}$ & 3.53 & 1.8 & 0.5 & 97.7 & - & - & 0.9 \\
\hline 287 & 40 & -1.58 & 34.248 & 0.218 & $\mathrm{~L}$ & 3.24 & 1.5 & 0.6 & 97.9 & - & - & 0.7 \\
\hline 287 & 49 & -1.22 & 34.465 & 0.279 & $\mathrm{~L}$ & 2.81 & 1.2 & 0.2 & 98.6 & - & - & 1.0 \\
\hline 310 & 10 & -1.82 & 34.188 & 0.210 & $\mathrm{~L}$ & 3.57 & 1.6 & 0.6 & 97.8 & - & - & 1.6 \\
\hline 310 & 29 & -1.83 & 34.217 & 0.218 & $\mathbf{L}$ & 3.66 & 1.6 & 0.6 & 97.9 & - & - & 1.6 \\
\hline 310 & 49 & -1.83 & 34.323 & 0.193 & $\mathbf{L}$ & - & 1.2 & 0.6 & 98.2 & - & - & - \\
\hline 310 & 64 & -1.79 & 34.380 & 0.245 & $\mathbf{L}$ & 3.61 & 1.2 & 0.4 & 98.3 & - & - & 2.1 \\
\hline 310 & 80 & -1.81 & 34.398 & 0.250 & $\mathrm{~L}$ & 3.56 & 1.2 & 0.4 & 98.4 & - & - & 1.6 \\
\hline 310 & 94 & -1.78 & 34.437 & 0.236 & $\mathrm{~L}$ & 3.42 & 1 & 0.4 & 98.5 & - & - & 1.2 \\
\hline 340 & 10 & -1.83 & 34.076 & 0.119 & $\mathrm{~L}$ & 4.07 & 1.5 & 1 & 97.5 & - & - & 2.4 \\
\hline 340 & 30 & -1.83 & 34.133 & 0.099 & $\mathrm{~L}$ & 4.02 & 1.3 & 1.1 & 97.6 & - & - & - \\
\hline 340 & 50 & -1.84 & 34.181 & 0.124 & $\mathrm{~L}$ & 4.51 & 1.2 & 1 & 97.8 & - & - & 2.2 \\
\hline 340 & 80 & -1.55 & 34.351 & 0.088 & $\mathbf{L}$ & 4.89 & 0.6 & 1.1 & 98.3 & - & - & 7.2 \\
\hline 358 & 15 & -1.79 & 34.028 & -0.38 & $\mathrm{H}$ & 6.03 & -0.6 & 3.1 & 97.5 & 91.1 & 13.1 & 6.4 \\
\hline 358 & 20 & -1.79 & 34.044 & -0.343 & $\mathbf{L}$ & 5.89 & -0.5 & 3 & 97.5 & 91.0 & 13.1 & 7.5 \\
\hline 358 & 44 & -1.84 & 34.199 & -0.215 & $\mathbf{L}$ & 5.42 & -0.3 & 2.4 & 98 & 92.7 & 13.3 & 6.5 \\
\hline 358 & 69 & -1.86 & 34.232 & -0.273 & $\mathbf{L}$ & 5.69 & -0.7 & 2.6 & 98.1 & 95.3 & 13.5 & 7.2 \\
\hline 358 & 89 & -1.86 & 34.235 & -0.300 & $\mathrm{~L}$ & 5.68 & -0.8 & 2.7 & 98.1 & 91.3 & 13.2 & 7.2 \\
\hline 358 & 109 & -1.49 & 34.324 & -0.033 & $\mathrm{~L}$ & 5.44 & 0.1 & 1.6 & 98.3 & 138.7 & 17.6 & 10.8 \\
\hline 358 & 124 & -1.241 & 34.383 & 0.026 & $\mathrm{~L}$ & 4.90 & 0.2 & 1.3 & 98.4 & 124.8 & 15.5 & 10.4 \\
\hline 358 & 138 & -0.72 & 34.450 & 0.048 & $\mathrm{~L}$ & 4.93 & 0.2 & 1.2 & 98.6 & 138.8 & 17.6 & 13.1 \\
\hline 362 & 20 & -1.81 & 33.868 & -0.745 & $\mathbf{L}$ & 7.56 & -1.9 & 4.7 & 97.2 & 94.7 & 13.4 & 6.8 \\
\hline 362 & 40 & -1.85 & 34.112 & -0.63 & $\mathbf{H}$ & - & -2.1 & 4.2 & 97.9 & - & - & - \\
\hline 362 & 59 & -1.85 & 34.168 & -0.592 & $\mathbf{L}$ & 7.43 & -2 & 4 & 98 & 108.2 & 14.6 & 9.2 \\
\hline 362 & 74 & -1.85 & 34.181 & -0.562 & $\mathbf{L}$ & 7.66 & -1.9 & 3.9 & 98.1 & 117.6 & 15.2 & 8.3 \\
\hline 362 & 89 & -1.83 & 34.206 & -0.52 & $\mathbf{H}$ & - & -1.8 & 3.7 & 98.1 & - & - & - \\
\hline 362 & 104 & -1.81 & 34.216 & -0.455 & L & - & -1.5 & 3.4 & 98.1 & - & - & - \\
\hline 362 & 132 & -1.36 & 34.301 & -0.03 & $\mathbf{H}$ & - & 0.2 & 1.6 & 98.2 & - & - & - \\
\hline 362 & 147 & -1.12 & 34.351 & 0.015 & $\mathrm{~L}$ & - & 0.3 & 1.4 & 98.3 & - & - & - \\
\hline 362 & 162 & -0.52 & 34.449 & -0.03 & $\mathbf{H}$ & - & -0.2 & 1.5 & 98.7 & - & - & - \\
\hline 364 & 21 & -1.80 & 33.607 & -1.103 & $\mathrm{~L}$ & 7.75 & -2.9 & 6.4 & 96.5 & 74.9 & 11.6 & 5.7 \\
\hline 364 & 30 & -1.81 & 33.686 & -0.985 & $\mathrm{~L}$ & 8.43 & -2.6 & 5.9 & 96.7 & 92.7 & 13.3 & 5.0 \\
\hline 364 & 40 & -1.84 & 33.905 & -0.839 & $\mathrm{~L}$ & 8.43 & -2.5 & 5.2 & 97.3 & 104.4 & 14.2 & 6.3 \\
\hline 364 & 49 & -1.84 & 33.928 & -0.770 & $\mathrm{~L}$ & 8.06 & -2.2 & 4.9 & 97.4 & 102.9 & 14 & 6.2 \\
\hline 364 & 59 & -1.84 & 33.960 & -0.793 & $\mathbf{L}$ & 7.93 & -2.4 & 5 & 97.5 & 98.6 & 13.7 & 6.5 \\
\hline 364 & 69 & -1.85 & 34.078 & -0.645 & $\mathbf{L}$ & 8.64 & -2.1 & 4.3 & 97.8 & 129.6 & 15.6 & 7.4 \\
\hline 364 & 83 & -1.85 & 34.123 & -0.599 & L & 7.57 & -2 & 4.1 & 97.9 & 109.8 & 14.8 & 8.4 \\
\hline 364 & 148 & -1.42 & 34.282 & -0.141 & L & 6.47 & -0.2 & 2.1 & 98.2 & 158.2 & 19.5 & 13.6 \\
\hline
\end{tabular}


Table 1. Continued

\begin{tabular}{|c|c|c|c|c|c|c|c|c|c|c|c|c|}
\hline Sta. & Depth & $\theta$ & Salinity & $\delta^{18} \mathrm{O}$ & Lab. & ${ }^{3} \mathrm{H}$ & $f_{i}$ & $f_{\mathrm{r}}$ & $f_{\mathrm{a}}$ & ${ }^{3} \mathrm{H}_{\text {runoff }}$ & $\begin{array}{l}\text { Vintage } \\
\text { age }\end{array}$ & ${ }^{3} \mathrm{H} /{ }^{3} \mathrm{He}$-age \\
\hline 365 & 25 & -1.81 & 33.580 & -1.065 & $\mathrm{~L}$ & 8.42 & -2.6 & 6.2 & 96.4 & 87.6 & 12.8 & 5.1 \\
\hline 365 & 49 & -1.84 & 34.083 & -0.714 & $\mathrm{~L}$ & 8.47 & -2.4 & 4.6 & 97.8 & 118.4 & 15.2 & 7.8 \\
\hline 365 & 74 & -1.86 & 34.127 & -0.620 & $\mathrm{~L}$ & 7.90 & -2.1 & 4.2 & 97.9 & 116.0 & 15.1 & 8.1 \\
\hline 365 & 99 & -1.83 & 34.171 & -0.523 & $\mathrm{~L}$ & 7.57 & -1.8 & 3.7 & 98 & 119.7 & 15.3 & 9.1 \\
\hline 365 & 119 & -1.81 & 34.208 & -0.455 & $\mathrm{~L}$ & 7.08 & -1.5 & 3.4 & 98.1 & 115.4 & 15.1 & 9.0 \\
\hline 365 & 138 & -1.53 & 34.258 & -0.170 & $\mathrm{~L}$ & - & -0.3 & 2.2 & 98.1 & $\ldots$ & - & - \\
\hline 365 & 158 & -0.83 & 34.400 & 0.008 & L & 5.66 & 0.1 & 1.4 & 98.5 & 174.0 & 19.0 & 14.9 \\
\hline 371 & 24 & -1.80 & 33.286 & -1.58 & $\mathbf{H}$ & - & -4.3 & 8.6 & 95.7 & - & - & - \\
\hline 371 & 40 & -1.80 & 33.289 & -1.413 & $\mathrm{~L}$ & 8.38 & -3.5 & 7.9 & 95.6 & 70.2 & 11.3 & 5.2 \\
\hline 371 & 49 & -1.84 & 33.834 & -0.892 & L & 8.63 & -2.6 & 5.5 & 97.1 & 103.2 & 14.1 & 6.5 \\
\hline 371 & 69 & -1.84 & 34.006 & -0.743 & $\mathrm{~L}$ & 0.00 & -2.4 & 4.8 & 97.6 & - & - & - \\
\hline 371 & 83 & -1.84 & 34.063 & -0.700 & L & 7.65 & -2.3 & 4.6 & 97.7 & 100.9 & 13.9 & 8.3 \\
\hline 371 & 99 & -1.85 & 34.115 & -0.661 & $\mathrm{~L}$ & 7.59 & -2.3 & 4.4 & 97.9 & 103.6 & 14.1 & 8.0 \\
\hline 371 & 119 & -1.83 & 34.160 & -0.553 & $\mathrm{~L}$ & 7.73 & -1.9 & 3.9 & 98 & 119.1 & 15.3 & 8.8 \\
\hline 371 & 157 & -1.19 & 34.321 & -0.16 & $\mathrm{H}$ & 6.59 & -0.5 & 2.1 & 98.3 & 158.4 & 18.5 & 14.1 \\
\hline 371 & 177 & -0.59 & 34.440 & 0.016 & L. & 6.73 & () & 1.3 & 98.6 & 260.0 & 20.2 & 15.6 \\
\hline
\end{tabular}

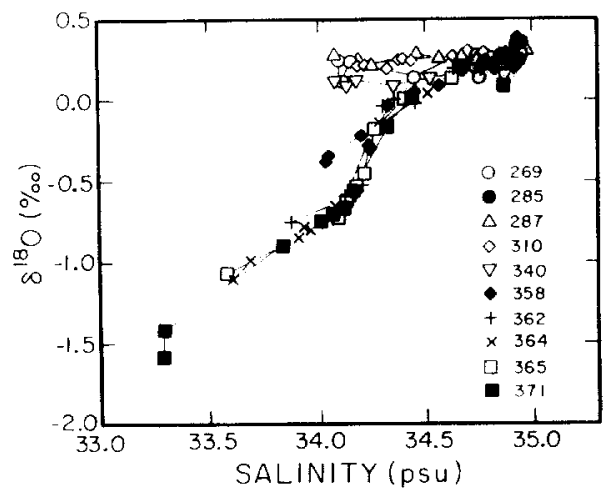

Fig. 7. Salinity versus $\delta^{1 \times} \mathrm{O}$ plot (for geographical position of the stations, sec Fig. 1).

halocline waters (Fig. 7) is strongly non-linear and is basically meaningless with respect to mixing considerations without additional information.

\section{Tritium vintage ages}

The tritium balance of the halocline waters is given by the following equation

$$
f_{\mathrm{a}} * T_{\mathrm{i} 1}+f_{\mathrm{r}} * T_{\mathrm{r}}+f_{\mathrm{i}} * T_{\mathrm{i}}=T_{\mathrm{m}}
$$

where $T_{\mathrm{a}}, T_{\mathrm{r}}, T_{\mathrm{i}}$ and $T_{\mathrm{m}}$ mean the tritium concentrations of the Atlantic water, the river-runoff, the sea ice meltwater and the measured halocline water, respectively. As both $T_{\mathrm{a}}$ and $T_{\mathrm{m}}$ are known and $T_{\mathrm{i}}$ can be assumed to be the same as the surface water tritium 


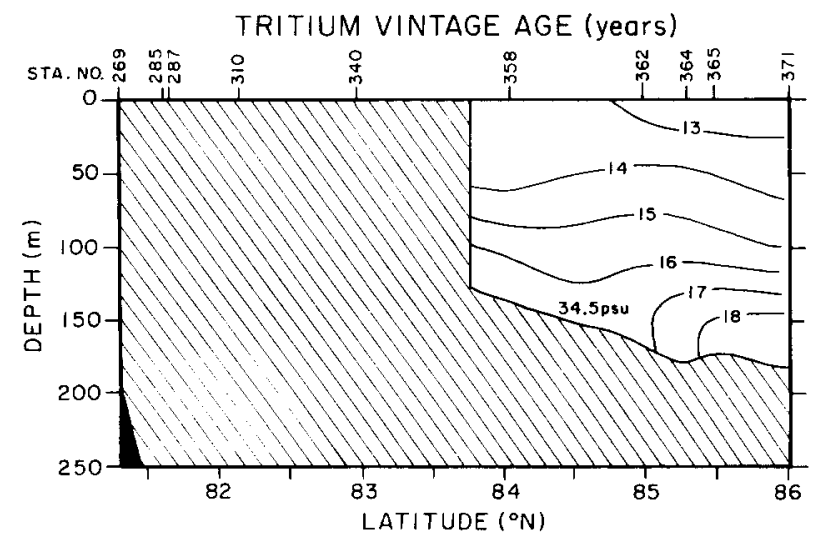

Fig. 8. Same as Fig. 4 for tritium vintage ages. The part of the section in which the river-runoff component used to determine the tritium vintage age is insignificant is shaded.

concentration measured at the individual stations, equation (4) can be resolved for the tritium concentration of the river-runoff component $T_{\mathrm{r}}$. Comparison of this tritium concentration with the time-dependent tritium curve for river-runoff principally allows estimation of the "vintage" of the river-runoff. This method was used by ÖstLunD and Hut (1984) to estimate the age of the freshwater component of the Arctic halocline. In our estimates we used values of $3.25 \mathrm{TU}$ for $T_{\mathrm{a}}$ and the surface values measured at the individual stations for $T_{\mathrm{i}}$ (range: $3.7 \mathrm{TU}$ at Sta. 269 to $10 \mathrm{TU}$ at Sta. 371). The calculated tritium concentrations of the freshwater component range from about 20 to about $260 \mathrm{TU}$ (reference year 1987; see Table 1). We did a straightforward comparison of these values with the tritium curve for river-runoff estimated by ÖSTLUND and HuT (1984) using a hydrological model developed by WeIss and RoETHER (1975) extended to 1987 using tritium measurements in precipitation published by the International Atomic Energy Agency. The comparison yields "freight train" ages of the river-runoff component of the freshwater between 9 and 20 years, with a general trend of increasing ages with increasing depth (Fig. 8, Table 1). This range is significantly higher than the values obtained by ÖSTLUND and Hut (1984; 8-10 years) and is similar to the range obtained using other tracers such as CFCs (WAllace and Moore, 1985; Wallace et al., 1987) or tritium/ $/ 3 \mathrm{He}$ (ÖStlund et al., 1982; Schlosser et al., 1990; WALlaCe et al., 1992).

\section{Comparison of tritium vintage ages and tritium $/{ }^{3} \mathrm{He}$ ages}

The ages of the freshwater component derived from the tritium data are systematically higher than the tritium $/{ }^{3} \mathrm{He}$ ages (Fig. 9). We interpret this difference as an indicator of the mean residence time of the freshwater component on the shelf. Figure 9 suggests a mean residence time of about 8.5 years. Because the freshwater component of the shelf waters leaving the shelves contains a mixture of river-runoff discharged during more than one year, and the tritium concentration in runoff is a non-linear function of time, the difference between the two ages might be misleading if interpreted in a straightforward manner. We therefore calculated the tritium concentration of the freshwater component of the shelf water for different storage times of the river-runoff on the shelf. For this calculation we 


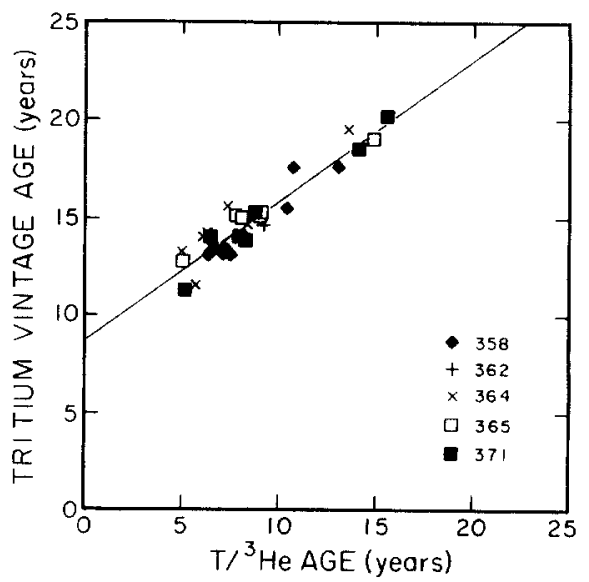

Fig. 9. Tritium vintage age versus tritium $/{ }^{3} \mathrm{He}$ age plot for the upper water column $(S>3.45)$.

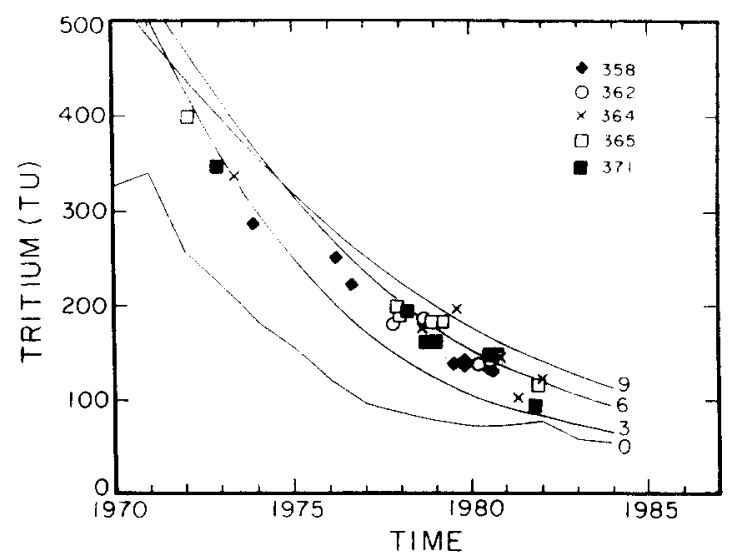

Fig. 10. Tritium concentrations as a function of time in the runoff component of shelfwater for different residence times of the shelf water (one-box model). According to their ${ }^{3} \mathrm{H}^{\beta} \mathrm{He}$-age, the calculated tritium values in the runoff component are included in the plot at the time 1987 minus the tritium $/{ }^{3} \mathrm{He}$ age for samples with salinities above 34.5 . For explanation, see text.

used the tritium curve for Arctic runoff as input function of a well-mixed reservoir (one-box model). The resulting tritium concentrations as functions of time are plotted for several mean residence times of the shelf water (Fig. 10).

We then can compare the river-runoff tritium concentrations estimated using equation (4) to the simulated tritium concentrations of the river-runoff component contained in shelf water. If we assume that the tritium $/{ }^{3} \mathrm{He}$ age reflects the time that has passed since the shelf waters entered the halocline, we can plot the tritium concentration of the runoff component contained in the halocline waters on the tritium curve at the time the water left the shelf $\left(1987\right.$ minus tritium $/{ }^{3} \mathrm{He}$ age; the values plotted on the $y$ axis represent the tritium concentrations at the time of runoff; Fig. 10). Most of the tritium points fall between the curves calculated for mean residence times of the freshwater component on the shelf of 3 
and 6 years, respectively, indicating a mean residence time of the river-runoff component of 3-6 years. The box model calculation was checked for consistency with salinity data and good agreement was found.

In most cases the tritium ${ }^{3} \mathrm{He}$ age of the shelf water is not zero due to limited exchange with the atmosphere. Therefore, the difference between the tritium age and the tritium $/{ }^{3} \mathrm{He}$ age has to be corrected to obtain a meaningful estimate of the mean residence time of the river-runoff on the shelf. We observed tritium $/{ }^{3} \mathrm{He}$ ages at our stations on the Barents shelf and close to the continental slope $(269,280$ and 287$)$ in the range of about $0.5-1.5$ years. If we correct the difference between the tritium ages and the tritium $/{ }^{3} \mathrm{He}$ ages for this initial tritium ${ }^{3} \mathrm{He}$ age, we obtain a best estimate for the mean residence time of the runoff component of about $3.5 \pm 2$ years. The scatter in our data reflects variations in both the mean residence times and the initial tritium $/{ }^{3} \mathrm{He}$ ages of the shelf waters.

Acknowledgements-This work profited from the contribution of numerous individuals and institutions: K. O. Münnich encouraged and supported major elements of our tracer studies in the Arctic Ocean. Jörn Thiede, chief scientist on ARK IV/3, provided time for an extensive tracer program. L. Anderson, P. Jones, P. Koltermann, B. Kromer, J. Swift and D. Wallace contributed to various aspects of the data collection. K. P. Koltermann and Jim Swift provided the salinity data. C. Junghans and J. Kontny measured part of the ${ }^{18} \mathrm{O}$ samples. Comments by John Milliman and an anonymous reviewer helped to improve the manuscript. The Alfred-Wegener Institute for Polar and Marine Research assisted in many logistical aspects. The officers and the crew of RV Polarstern provided excellent technical support. We are grateful to Patty Catanzaro for drafting the figures. Financial support by the German Science Foundation, the National Science Foundation under grant No. DPP 90-22890 and the Office of Naval Research under grant No. N00014-90-J-1362 is gratefully acknowledged. L-DEO contribution No. 5195 .

\section{REFERENCES}

AagaARD K. and E. C. CARmack (1989) The role of sea ice and other fresh water in the Arctic circulation. Journal of Geophysical Research, 94, 14,485-14,498.

AagaARD K. and L. K. Coachman (1975) Toward an ice-free Arctic Ocean. EOS, 56, 484-486.

Aagaard K., L. K. Coachman and E. Carmack (1981) On the halocline of the Arctic Ocean. Deep-Sea Research, 28, 529-545.

Anderson L. G., E. P. Jones, K. P. Koltermann, P. Schlosser, J. H. Swift and D. W. R. Wallace (1989) The first oceanographic section across the Nansen Basin in the Arctic Ocean. Deep-Sea Research, 36, 475-482.

Bayer R., P. Schlosser, G. Bönisch, H. Rupp, F. Zaucker and G. Zimmek (1989) Performance and blank components of a mass spectrometric system for routine measurement of helium isotopes and tritium by the ${ }^{3}$ He ingrowth method. In: Sitzungsber. Heidelb. Akad. Wissensch., Math. Naturwiss. K1., Jahrgang 1989 , Vol. 5, Springer-Verlag, Berlin pp. 241-279.

BeCK N. and K. O. MüNnich (1988) Freezing of water: isotopic fractionation. Chemical Geology, $70,168$.

Clarke W. B., W. J. Jenkins and Z. Top (1976) Determination of tritium by mass spectrometric measurement of ${ }^{3}$ He. International Journal of Applied Radiation and Isotopes, 27, 515-522.

Greenland Sea Project Group (1990) Greenland Sea Project, a venture towards better understanding of the oceans' role in climate. Eos, Transactions of the American Geophysical Union, 71, 750-751, 754-755.

Hanzlick D. and K. AagaARo (1980) Freshwater and Atlantic Water in the Kara Sea. Journal of Geophysical Research, 85, 4,937-4,942.

Jones E. P. and L. G. Anderson (1986) On the origin of the chemical properties of the Arctic Ocean halocline. Journal of Geophysical Research, 91, 10,759-10,767.

Jones E. P., L. G. Anderson and D. W. R. WAllace (1991) Tracers of near-surface, halocline and deep waters in the Arctic Ocean: implications for circulation. Journal of Marine Systems, 2, 241-255.

Östlund H. G. (1982) The residence time of the freshwater component in the Arctic Ocean. Journal of Geophysical Research, 87, 2,035-2,043.

Östlund H. G. and G. Hut (1984) Arctic Ocean water mass balance from isotope data. Journal of Geophysical Research, 89, 6,373-6,381. 
Óstlund H. G., Z. Top and V. E. LeF (1982) lsotope dating of waters at Fram III. Geophysical Research Letters, 9, $1117-1119$.

Peirman S. L., M. A. Lange, I. Wollenburg and P. Schlosser (1990) Sea ice characteristics and the role of sediment inclusions in deep-sea deposition: Arctic-Antarctic comparisons. In: Geological history of the Polar Oceans: Arctic versus Antarctic, U. BIEIL, and J. THIEDE, editors, Kluwer Academic Publishers. Amsterdam, 187-211 pp.

PSSP (Polarstern Shipboard Scientific Party) (1988) Breakthrough in Arctic Deep Sea Research: the RV Polarstern Expedition 1987. Eos, Transactions of the American Geophysical Union, 69, 665, 676-678.

Schlosser P. (1985) Ozeanographische Anwendungen von Spurenstoffmessungen im Mittelmeerausstrom und im Europäischen Nordmeer. Ph.D. thesis, Universität Heidelberg, Germany.

Schlosser P., G. Bönisch, B. Kromer, K. O. Münnich and K. P. Koltermann (1990) Ventilation rates of the waters in the Nansen Basin of the Arctic Ocean derived from a multi-tracer approach. Journal of Geophysical Research, 95, 3,265-3,272.

Schlosser P., G. Bönisch, M. Rhein and R. Bayer (1991) Reduction of deepwater formation in the Greenland Sea during the 1980s: evidence from tracer data. Science, 251, 1054-1056.

WALl.ACE D. W. R. and R. M. Moore (1985) Vertical profiles of $\mathrm{CF}_{2} \mathrm{Cl}_{2}(\mathrm{~F}-12)$ and $\mathrm{CCl}_{3} \mathrm{~F}$ (F-11) in the Central Arctic Ocean Basin. Journal of Geophysical Research, 90, 1155-1166.

Wat lace D. W. R., R. M. Moore and E. P. Jones (1987) Ventilation of the Arctic Ocean cold halocline: rates of diapycnal and isopycnal transport, oxygen utilization, and primary production inferred using chlorofluoromethane distributions. Deep-Sea Research, 34, 1957-1979.

Wallace D. W. R., P. Schlosser, M. Krysel.l and G. Bönisch (1992) Halocarbon and tritium/ ${ }^{3}$ He dating of water masses in the Nansen Basin, Arctic Ocean. Deep-Sea Research, 39, 5435-5458.

Weiss W. and W. Roether (1975) Tritium run-off of the Rhine River 1961-1973. Dtsch. Gewaesserkd. Mitt., 19. 1-5. 